\title{
Statyba
}

\section{A DECISION SUPPORT SYSTEM APPLYING MULTICRITERIA SYNTHESIS METHODS IN CONSTRUCTION}

\section{V. Šarka}

To cite this article: V. Šarka (2000) A DECISION SUPPORT SYSTEM APPLYING

MULTICRITERIA SYNTHESIS METHODS IN CONSTRUCTION, Statyba, 6:6, 464-468, DOI: 10.1080/13921525.2000.10531632

To link to this article: https://doi.org/10.1080/13921525.2000.10531632

曲 Published online: 26 Jul 2012.

Submit your article to this journal $₫$

Џ Article views: 64 


\section{A DECISION SUPPORT SYSTEM APPLYING MULTICRITERIA SYNTHESIS METHODS IN CONSTRUCTION}

\section{V. Šarka}

\section{Vilnius Gediminas Technical Universit!}

\section{Introduction}

The construction industry, compared to other industries, is distinguished by a small productivity of work and large fragmentation. This is a complex system connected by close ties, still being quickly developed, and sensitively reacting to environmental effects. A great number of projects are being constantly implemented there (new construction, building reconstruction and heating renovation, attraction of investment, etc) distinguishing one from another by purposes, volumes and other features.

In investigating any problem connected with certain construction fields: new residential, industrial, commercial, administration building construction, reconstruction or renovation, bridge building, installation of the utility networks, infrastructure creation, the construction materials industry, etc, tremendous problems are encountered. Solution of these problems requires a great deal of time and financial resources. This research enumerates the largest elements describing the construction process. After a deeper investigation. we will see that it is possible to separate each of these processes into several, even quite a few, smaller processes or projects.

Having such a variety of elements participating in the construction process. the necessity araises to reciprocally co-ordinate these activities. Io collaboratc on various issucs. exchange information. and share the experience possessed.

A nell decision support system (DSS) using the latest information technology is being developed wo implement joint projects. The decision support system is designated to accumulate and process initial data using various mathematical and logical models including multicriteria assessment methods. The DSS then provides the decision-maker with the information necessary to analyse, create, assess, and make a decision concerning alternatives to possible decisions. At last there was a possibility to obtain and store the results obtained.

\section{The work aim and research subject}

Describing the preconditions set forth after making assertions clarifies the investigation problem connected with the possibility of applying certain multicriteria decision selection methods in the field of construction technology.

The author's purpose was to investigate the current decision support systems and the mathematical models used in them as well as to improve them by introducing several multilevel, multicriteria decision synthesis methods. The proposed methods must correspond to the nature of the problems being resolved and take into consideration the modern view applied to multicriteria decision-making. Based on this, the primary assertion of this research is the following.

Applying corresponding methods according to a procedure assuring a correct course for this process must solve problems of multicriteria decisions by construction technology engineers. with the group of variants known and defined in the decision selection process in the beginning. According to the assertion set forth above in this research. the following aims are being pursued:

- to select those methods. which are the newest and most representatice. taking into consideration various siewpoints applied in the multicriteria decision method according to the problems in organising many indexes:

- to investigate once and for all and to apply many indexes for solving a task, three new multilevel. multicriteria decision synthesis methods (for the first time synthesis methods were mentioned in 1991 in the work of Prof E. K. Zavadskas [1], however no final analysis and adaptation were provided); 
- to combine 3 new multicriteria decision syntheses, several multicriteria decision-making methods (for separate stage decisions) and expert methods in a newly created decision support system applying multicriteria synthesis methods (DSS_MS) for construction software work:

- to prepare an initial database devoted to DSS_MS for construction.

The subject of the research is multicriteria decision theory and decision support system. Theoretical multicriteria assessment and expert methods are used in pursuing the aforementioned aims.

A thorough description of the scientific research performed and the results obtained is presented in the author's thesis [2].

\section{Contents of the research}

The primary focus of this research is to clarify the possibilities of using multicriteria decision selection method in an effort to solve the problems of decisionmaking connected with the construction industry. The development of the multicriteria decision-making methods is presented here. Also, there are briefly presented the connections and problems of the multicriteria decision-making method. The development of the investigation method and the existing single level multicriteria decision-making manner in the construction technology field is investigated. In the first chapter [2]. there is a brief review of several decision support systems DSS used abroad and in Lithuania.

In the second chapter [2] are presented the fundamental aspects of the new decision support system created by the author. Here are described the principal two main structural elements of the decision support systems: data (databases and their control system) and the principal elements of the model base structure (the structure of the multicriteria assessment and expert methods used in the system).

Besides the alorementioned assertion. an initial database for the decision supporn system in construction and structural schemes for decision-making hase been created. A thorough description of the proposed database structure (DBS) and the multicriteria decision-making structure scheme are presented by the author [2]

The structure of the decision support system applying multicriteria synthesis methods (DSS_MS) in construction is based a systematic-technical assessment of the projects (PSI) [3, 4], expert assessment [4, 5], and the multicriteria decision synthesis methods proposed by the author [2]:

- a method of project synthesis by a compromise compensation model (SKK3) [2, 6];

- a method of project multicriteria decision synthesis (DSSI) on the basis of decision success criterion (PSS1) $[2,7]$;

- a method of project multicriteria decision synthesis (DSS2) according to average weighted decision-making success (VSPSSI) [2].

The aim of a decision by these methods is to combine for the investigated construction complex, the alternatives of the several analysed construction processes or projects into a general construction system decision tree (DT) (Fig).

By this it is sought to avoid possible errors arising in future construction, which is already in the stages of the establishment of its future purposes and in the design stage. Then investigating also properly and complexly the design questions related to future construction, performing a complex analysis of possible construction materials and equipment used for construction, analysing the possibilities of the construction labour market, and resolving many of the quantity questions connected with construction, it is possible to accumulate a large amount of time and material resources connected with construction processes. These questions were and are very important at the level of each state, each firm, and each individual person. For the solution of these questions, a great deal of time and force is allocated worldwide. Thus, the author. after investigating current situation. has noted a tendency in the creation of the existing and newly created decision support systems that most of DSS created systems in Lithuanias and the world are developed to pursue only one or another specific aim. Huge expenditures of time and funds are allewated to create every DSS system.

The crealled systems work only in very concrete. specific areas of construction. econumics. ens ironmental protection. elc. Mostly solve questions at one level of the area being investigated. A solution can be made only in a concrete and so assigned direction of DSS activity. It is not foreseen in the system to perform complex, multilevel decision except the existing variant 


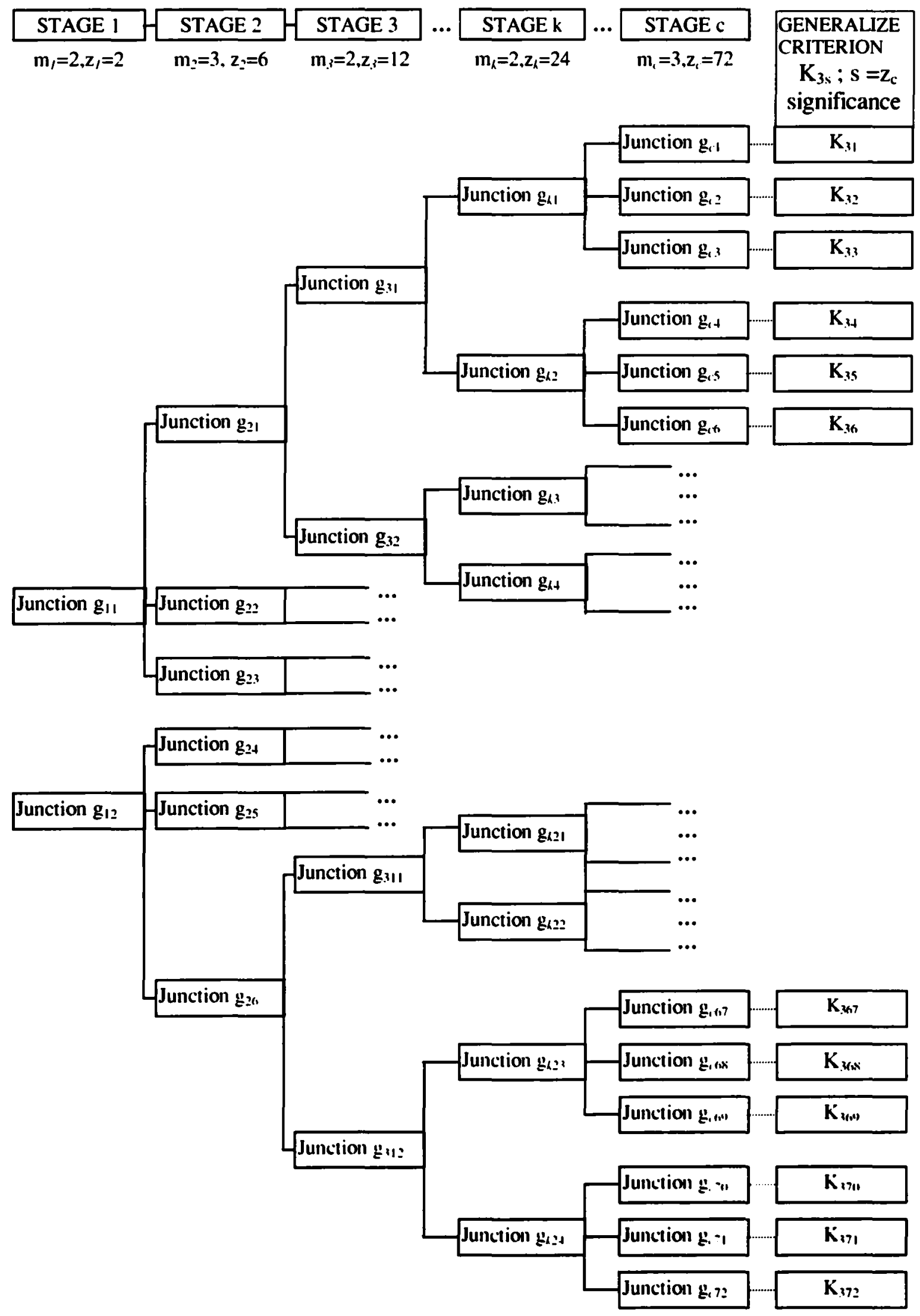

Fragment of decision tree (DT) formation structure with multicriteria project synthesis methods 
design methods and practical application examples found in the work of E. K. Zavadskas and A. Kaklauskas [3], C. L. Hwang and K. Yoon [4].

The author, through his three multicriteria decision synthesis methods, has sought:

- to investigate the possibilities of multilevel decision execution and the problems connected with it:

- to eliminate the gap created in the system of multicriteria decision methods and to create three multilevel multicriteria decision synthesis methods integrated into a DSS:

- to adapt the system being created together with the integrated synthesis methods to the solution of as great a diversity of complex questions as possible.

\section{Practical application of the scientific research}

In order to check the reliability of the newly created system, there was created a decision support system computer model, applying multicriteria synthesis methods (DSS_MS), which is designated to solve equipping design problems of component parts of a building, combining them into a general totality with the assistance of synthesis methods. In this system additional programming measures are used for solving undefined questions: methods of expert assessment and pair comparison. Various methods for project system technical assessment are proposed for solving single level multicriteria assessment tasks.

DSS_MS in construction is designated for engineers, experts, construction technology-management students, and other users. As a teaching aid, this system should assist students to better understand as well as to independently master and learn new concepts and the methods connected with the multicriteria decision methods that are becoming ever more popular. As an applied system. the programme can analyse multilevel tasks for the most complex structures. which frequently. arise in the complex construction industry. The control of the sofiware system part as well as the creation and filling of the database structure is simple and do not need a large additional expenditure of labour. The system has an internal control mechanism for self-control with certain author assigned parameters.

The packet provides the possibility of:

- systematically storing the initial data connected with various technical decisions;
- performing an analysis of the initial data possessed and processing it:

- solving problematic questions of the management of undefined data by the expert method;

- according to the analysis performed, making effective decisions in both single level (proximity to the ideal point, multicriteria complex proportion assessment methods for projects) and multilevel (multicriteria decision synthesis methods) systems created from multicriteria decisions;

- protecting the results of realised projects in a database and providing this data for repeated analysis as well as for the creation of other initial databases:

- printing the initial data and results in the shape of forms specially prepared for it.

By applying the DSS_MS computer model created by the author, there are presented 2 actual examples, solved by the author with the assistance of multicriteria analysis synthesis methods, of several construction elements and construction processes as well as of ongoing construction:

1. The selection of the most effective construction elements of Polish Houses using the method of synthesis and compromise compensation models (SKK3). By this method the most effective construction solution variant was calculated. It includes exterior walls, foundation, roofing, windows and partitions. An initial DSS_MS construction base was also created.

2. The selection of the most efficient construction elements and the construction process of a 6-floor administration building in Vilnius were made using the multicriteria decision synthesis (DSSI) method.

With this specific case were solved the questions of investigation projects. \& constructive elements (bui)ding skeleton. glass panitions and automatic doxss. ventilation and air conditioning system. building̣ faccade finishingl as well as the selection of a contractor.

3. The selection of the most efficient construction variant for a one-flat residential house using the project of the multicriteria decision synthesis method (DSS2) according to average weighted decision-making success (VSPSSI) criterion was made. 


\section{General conclusions}

1. A new decision support system management procedure in construction was created. It assures a correct decision selection process, especially taking into consideration a selected explanation method for decision multitask problems.

2. Three multicriteria synthesis methods were created:

a) a method of project synthesis, using a compromise compensation model (SKK3) was improved:

b) a method for project multicriteria decision synthesis (DSS I), on the basis of decision success criterion (PSSI) was created:

c) a method for project multicriteria decision synthesis (DDS2), according to average weighted decisionmaking success (VSPSS 1 ) criterion, was improved.

3. The method of proximity to the ideal point was improved by introducing the absolute mutual significance of single level of alternatives (TOPSIS_A).

4. A new term was introduced: single level, alternative absolute mutual significance.

5. A theoretical and computer model for a decision support system applying multicriteria synthesis methods (DSS_MS) with the aforementioned system elements integrated were created.

6. The reliability of all three synthesis methods was tested by calculated experiments. The results of the assessment of two methods were applied in the concrete projects actually implemented.

All this allows one to assert that multicriteria decision synthesis methods are theoretically fully described and mathematically grounded. All three synthesis methods created are part of the classification scheme of project technical assessment methods and are designated to solve problems through multiple level multicriteria decisions.

\section{References}

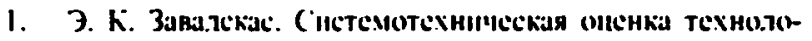

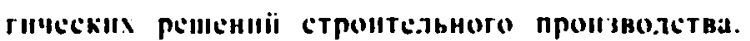

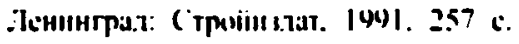

2. I: Sarka. Dauglaktriceriniy sprendimu sentezi. parenkiant racionallus pastatu lechnolog̣imsus-orL̨anizacimius variantus. Dukitaro discracija: lechnologijon mokslad. statytos inżinerija VC(TL: Vilnius. 2000. I80 $\mathrm{p}$.

3. E. K. Zaradskas. A. Kaklauskas. Pastaty sistemolechninis iverinimas. Vilnius: Technika. 1996. 280 p.

4. C. L. Hwang. K Yoon. Multiple attribute decision making - methods and applications, a state-of-the-at survey, Berlin: Springer Verlag. 1981.
5. K. Yoon and C. L. Hwang. TOPSIS (technique for order preference by similarity to ideal solution) - a multiple attribute decision making. $w$ : Multiple attribute decision making methods and applications. a state-of-the-art survey. Berlin: Springer Verlag. 1981, p. 128-140.

6. V. Šarka. L. Ustinovičius. E. K. Zavadskas. Projektu sintezi naudojant kompromiso kompensacinius modelius statybojc /: Statyba (Civil Engineering). V t.. Nr. 6. Vilnius: Technika. 1999, p. 374385.

7. V. Sarka. E. K. Zavadskas. L. Ustinovičius. Projektu daugiakriteriniu sprendimu sintezės remiantis priimamo sprendimo sékmés kriterijumi metodas // Statyba (Civil Enginecring). VI t.. Nr. 3. Vilnius: Technika. 2000. p. 193- 201.

|tcikta 20001212

\section{SPRENDIMU PARAMOS SISTEMA, TAIKANT DAUGIA- KRITERINIUS SINTEZES METODUS STATYBOJE}

\section{v. Sarka}

Santrauka

Autorius savo moksliniu tyrimų pagrindu pasirinko daugiakriteriniu sprendimy prièmimo metodiką, sios metodikos problematika ir tyrimo metodu plètrą.

Nagrinejami esami vienpakopiai daugiakriteriniu sprendimų prièmimo būdai statybos technologijos srityje bei autoriaus siūlomi daugiapakopiai daugiakriteriniu sprendimų sintezès metodai.

Atskiru struktūru sujungimo i bendra sistemą kartu sprendžiant skirtingose pakopose esančiu altematyvu tarpusavio ryšiu suderinamumo problemas nagrinejimas yra labai svarbus daugiakriteriniu sprendimu srityje. Sprendimo šiais metodais tikslas yra nagrinèjamame statybos komplekse sujungti keliu analizuojamu statybos procesu ar projektu altematyvas i bendra statybos sistema. Tuo yra siekiama dar tikslu nustatymo bei projektavimo stadijose išvengti galimu klaidu būsimoje statyboje.

Autoriaus patobulinti ir sukurti projekty daugiakriteriniy sprendimu sintezès metodai yra nauja daugiakriteriniy sprendimu metodu šaka. Pagal sukurtı daugiakriterinių sprendimц sintezès metody algoritmus parengti kompiuteriniai metodu modeliai yra integruoti i naujai sukurtą sprendimu paramos sistemą statybojc SPS_DS.

Pagal SPS_DS sistemą atlikti praktiniai tyrimai. Patcikti autoriaus issprestey dicicjy realiai pastatyly pastaty keliy konstrukciniy elementy bei statybos procesy daugiapakopes dauglakriterincis analizes sintezes metedais patyzzdżiai. Taip pat sukurta pradini SPS DS statybojc kai kuriuos konstrukcinius clementus Ipastato karkasa. isorines sienas. pertsaras. fasado

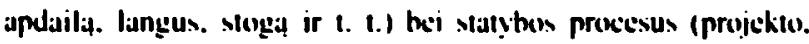
rangeowo parinkimal aprasianti duomenu hazci (DBS).

Vaidotas SARKA. Dector (lechnolugical sciences). Vilnius Gidiminas Technical University (VGTU). Saulcetekio al. II. LT-2040 Vilnius. Lithuania. E-mail: E Raud(u centras.lt

A graduate of Vilnius Technical University (1993). Doctor (2000). Author of 7 publications. Research interests: decision support systems, multicriteria decision methods, project management, and computerised design. 